\title{
Digital Culture, New Media and The Transformation of Collective Memory Dr. Gökçen BAŞARAN INCE
}

goldsmiths, university of london, center for cultural studies g.ince@gold.ac.uk

\begin{abstract}
Along with the advent of digital technologies, modern and "semimodern" societies met a new phase of temporality. Speed, mobility and globality epitomise the fundamental characteristics of this process. New media, as a form of communication that consist of "digitality, interactivity and hypertextuality", enable the genesis of a new memory culture in which audiences act as memory "prosumers". Yet it is dubious whether this new era will lead to a "memory boom" or a "digital amnesia" when one takes into account the material restrictions of digital platforms, like their lifespan. This article aims to discuss the possibilities/impossibilities of the digital communication and understand its contributions to the construction of collective memory.
\end{abstract}

keywords: digital culture, new media, collective memory, digital amnesia, social media 


\section{Résumé}

\section{Culture digitale, nouveaux médias et la transformation de la mémoire collective}

Avec l'apparition des technologies digitales, les sociétés modernes et semi modernes ont commencé à reconnaître une nouvelle forme de temporalité dont les caractéristiques principales sont la mobilité et la globalisation. Les nouveaux médias qui permettent la digitalité, l'interaction et l'hyper textualité ont conduit à une nouvelle culture de mémoire dans laquelle le spectateur pourrait exister à la fois comme producteur et comsommateur (prosumer). Pourtant, en considérant la limite des téchnologies digitales, cela ne parait pas possible d'affirmer que ce procès causera "une explosion de mémoire" ou "une amnésie digitale". Le but de cet article est de discuter des possibilités et impossibilités de la communication digitale dans la construction de la mémoire collective.

mots-clés : culture digitale, nouveaux médias, mémoire collective, amnésie digitale, médias sociau

\section{Özet}

\section{Dijital Kültür, Yeni Medya ve Toplumsal Hafızanın Dönüşümü}

Dijital teknolojilerin ortaya çıkışı ile birlikte, modern ve yarı-modern toplumlar, hız, akışkanlık ve küreselliğin temel karakteristikler olarak sayılabileceği, yeni bir zamansallık biçimi ile tanıştı. Dijitallik, interaktivite ve hipermetinsellik sağlayabilen yeni medya, izleyicinin aynı anda hem üretici hem tüketici (prosumer) olarak varolabildiği yeni bir hafıza kültürünün doğuşunu sağladı. Ancak dijital teknolojinin kısıtıııkları düşünüldüğünde, bu sürecin bir "hafıza patlaması"na ya da "dijital amnezi"ye dönüşeceğini söyleyebilmek mümkün görünmemektedir. Bu makalenin amacı toplumsal hafızanın inşasında, dijital iletişimin imkân ve imkânsızlıklarını tartışmaktır.

anahtar kelimeler: dijital kültür, yeni medya, kolektif bellek, dijital amnezi, sosyal medya 


\title{
Introduction
}

Being away from home for sometime, I had to communicate with family and friends via e-mail and visual talks. After having my mother as a guest and sending her back home, a crucial point stuck to my mind: what would I do if I had lost all the e-mails? There would not be one single memory of the special correspondence if I had lost these "bits" of memory. The digital data was so elusive, so insecure and immaterial to provide a longlasting memory, I decided to send postcards to some people via mail. They still await to be sent. Sure these were worries for my autobiographical memory, yet are they not valid for collective memory as well?

To some "With the advent of digital technologies, remembering has become the norm and forgetting the exception. Four main technological drivers have facilitated this shift: digitization, cheap storage, easy retrieval, and global reach" (Mayer-Schönberger 2009: 52). Despite the facts such as "digital divide" and "digital illiteracy" which indicate the economic gap or political differences between societies resulting in inequalities in access to digital technologies (Doueihi 2011: 13), the genesis of a global network community that keeps in touch through digital channels is apparent. Some already utter about the rise of a "globital memory" (Reading 2012) to refer to the universal character of multiple temporalities and experiences of time in the global age in which a common memory reservoir is possible. Thinking about Neda Agda Sultan's being shot to death during Iranian protests in 2009 and the speed of the dissemination of the video to the whole world showing her last moments make one think that a global memory might be possible. ${ }^{1}$ The solidarity of the world for the Soma mine disaster also indicate the possibility of a world wide, "short-term" digital memory. ${ }^{2}$ Yet it is dubious whether these instant sharings could lead to a long term collective memory. Donk's remarks substantiate the concerns for a "Digital Dark Age"3:

\begin{abstract}
"Software and hardware evolve in such a fast way that incompatibility between formats seems inescapable; digital media storage media like CD, DVD or even hard drives do not last for more than 20 years and can be easily deleted; and Internet and mail communication tend to be elusive as Internet sites vanish without being archived" (Donk, 2009: 1).
\end{abstract}

1 The image of Neda's face, covered in blood, was recolored, reconfigured, and reassembled across multiple media forms. The witness video prompted the creation of a number of memorial websites, a Twitter icon, a number of Facebook groups, two Wiki pages, memorial art works, and songs commemorating Neda's life and death (Reading, 2011: 241).

2 After the death of 301 miners in Soma due to a mine fire, in Turkey, May 2014, there had been a global solidarity digitally. Pop singer Rihanna tweeted about Soma to her 35 million followers. Football clubs Liverpool, Chelsea, Schalke, Borissia Dortmund also tweeted and gave their condolences. There had been a national digital unity as well. 14,100 messages were tweeted at that very day.

3 The concept belongs to Stewart Brand. See Brand, S. (2003), "Escaping the Digital Dark Age", Library Journal, 124: 46-49. 
The concerns for the physical durability of the digital technologies may remind the influence of "medium theories which mean a paradigm shift from content to technology [in which] effect are primarily not caused by media content but by the material basis of communication" (Donk 2009: 6). The medium is an indispensable component which impinge the content and effects of the communication process, functioning concomitantly with the rest of the means that cannot be confined to linear effects from the medium. The political economy of the media system, the historical background and the political culture of the societies intermingle in the construction of the meaning. For this reason, the focus of this study concurs with the idea that the technological change is interdependent with society's construction of reality from a "social constructivist" approach.

\title{
Digital Culture and New Media
}

$$
\begin{aligned}
& \text { - ruok? } \\
& \text { - idk } \\
& \text { - t+ hun ıly } \\
& \text { - t2ul } \\
& \text { - ok cul8r }
\end{aligned}
$$

\author{
(are you ok?) \\ (i dont know) \\ (think positive honey, i love you) \\ (talk to you later) \\ (ok, see you later)
}

Milad Doueihi has an idea to evaluate the text messaging above, explaining the immense transformation through which modern societies pass:

\begin{abstract}
Digital culture is the only rival to religion as a universal presence. The much discussed and celebrated transition from analog to digital and all that it entails amounts to a conversion, in the technical as much as the religious sense of the term (...) It is precisely because of this seemingly inevitable process of conversion that digital culture, no matter how vaguely we define it, is laying a claim for the status of an equivalent of a world religion with its prophets and priesthood, its institutions and sects and believers, its dissenters and schismatics. It has its own language that has filtrated and begun to reshape the spoken and written languages (think, for an example, of the influence of SMS on our linguistic practises and of the online-inspired typography, the use of capitals, etc.) Our learned literacy is slowly but surely under the influence of the emerging practises of digital literacy. (2011: 3)
\end{abstract}

Despite time's potency to indicate the effects of this huge transition, it is obvious that the digital culture "shapes everyday life across its multiple facets, for everyone, just as electiricity and print were seen as doing in previous eras" (Thumim 2012: 10). Pessimist views utter about the "digital vertigo" (Keen 2012) or the "digital nomadicity" (Gitlin 2011) to emphasize alienation. Some speak about the "digital unconscious" to stress the obscured and taken for granted features of digitality and digitization that may be changing human consciousness (Monk 1998, cited by Reading 2011: 244). That said, these transformations already set the dynamics of a new form of society. 
Scholars working on the history of communication emphasize some major changes like the invention of writing, the telegraph or the printing technologies. The phenomenon of 21 st century seems to be the transition to the digital technologies and the concomitant rise of the "network society" (Dijk 2012: 3 and Castells 2004 and 2010). A network society is a society whose social structure is made of networks powered by microelectronics-based information and communication technologies (Castells 2004: 8). This network effects the overall dimension of human relations including the production relations, consumption, reproduction and power (Castells 2004). Dijk summarizes the features of the network society as follows:

A modern type of society with an infrastructure of social and media networks that characterizes its mode of organization at every level: individual, group/ organizational and societal. Increasingly, these networks link every unit or part of this society (individuals, groups and organizations) (Dijk 2012: 24).

Castells also argues the distinctive characteristics of the network society and notes that three main features of the technologies of this system make it unique and different than the printing, the telegraph or the non-digital telephone:

- $\quad$ their self-expanding processing and communicating capacity in terms of volume, complexity, and speed

- their ability to recombine on the basis of digitization and recurrent communication;

- $\quad$ their distributing flexibility through interactive, digitized networking (Castells, 2004: 9).

It is of importance to note that this type of network is specific to "Western" countries like "North America, Europe and high-income Asia-Pasific countries where people hold almost 90 per cent of total world wealth" (Curran 2012: 9). The internet access of societies indicates the unequal distribution of the information technologies around the world 4 . There are many developing countries with Internet penetration rates that are less than 1/100th of those wealthy countries" (Wunnava and Leiter 2009:413, cited by Curran 2012:9). An important feature of the non-Western societies is their "hybrid" character in which some of the features of network, information and mass societies intermingle. 5 For instance "Rapid adoption and high rate of use of mobile

4 Statistics in 2013 for "Internet users in the world" are as follows: Asia 45.1\%, Europe 20.2\%, North America 10.7\%, Lat.Am/Caribb 10.8\%, Africa 8.6\%, Middle East 3.7\%, Ocenia/Aust. 0.9\%. http://www.Internetworldstats.com/stats.htm, date of access: 31.08.2014.

5 Dijk defines the "information society" as an organization of society based on science, rationality and reflexivity; an economy with all values and sectors, even the agrarian and industrial sectors, increasingly characterized by information production; a labour market with a majority of functions largely or completely based on tasks of information processing requiring knowledge and higher education (hence, the alternative term knowledge society and a culture dominated by media and information products with their signs, symbols and meanings). His definition of "mass 
phones and texting in economically underprivileged communities and even more so in some underdeveloped nations" (Doueihi 2011: 14) are indications of this hybridity. The dissemination of some characteristics of the "network society" to the underprivileged parts of the world and the localization of the concept is an apparent situation.

A distinguishing feature of the network societies seems to be the transition from analog to digital media, namely the "new media". Keeping in mind the relativity of "newness" and the criticism on the term" 6 , scholars agree that the new media is "a combination of online and offline media, such as the internet, personal computers, tablets, smart-phones and e-readers. They are a combination of transmission links and artificial memories (filled with text, data, images and/or sounds) that can also be installed in seperate devices" (Dijk 2012: 5, Manovich 2001, Aitchison and Lewis 2006, Logan 2010). Digitality, interactivity, hypertextuality, being networked and simulated (Lister et al. 2009: 13) are some other features of that media.

According to Logan the "newness" of the new media stand for "its permitting a great more participation of its users who are no longer just passive recipients of information but are active producers of content and information" (Logan 2010: 6). "Prosumers" (Lister et.al, 2009) both produce and consume the content of the messages in the new media. In comparison with the belated "audience feedback" of the "old media", active participation and interactivity seem to be the norm here. Logan epitomises the reasons of the "newness" of the new media as follows:

What is new about today's "new media" is that they are digital, they are linked and cross-linked with each other and the information they mediate is very easily processed, stored, transformed, retrieved, hyper-linked and perhaps most radical of all easily searched for and accessed (Logan 2010: 7).

The new media is also asserted to offer a remedy to the criticism of Frankfurt School's "mass culture". Lister et. al notes that the new media bring in

(...) "the recovery of community and a sphere of public debate, providing removal of information and communication from central authority, control and censorhip. The "fourth estate" function of mass media, seen here to be

society" is as follows: "A modern type of society with an infrastructure of groups, organizations and communities (called 'masses'), that shape its prime mode of organization at every level (individual, group/organizational and societal). The basic units of this society are all kinds of relatively large collectivities (masses) organizing individuals" (Dijk, 2012: 23- 24).

6 Lister et al. believe that the stress on the "newness" of "new media" has strong ideological connotations. "These connotations of 'the new' are derived from a modernist belief in social progress as delivered by technology and (...)the celebration and incessant promotion of new media and ICTs in both state and corporate sectors cannot be dissociated from the globalising neo-liberal forms of production and distribution which have been characteristic of the past twenty years" (Lister et. al, 2009:11). 
revived with the rise of the 'citizen journalists' as alternative sources of news and information circulate freely through 'blogs', online publishing, cameraphone photography" (2009: 76).

Yet the counter-views say the opposite, claiming of a "net delusion" (Morozov 2011) which indicates how the new media become crippled along with the interventions and prohibitions of authoritarian or semi-authoritarian regimes. It is also determined that the usage of social media during ptotests in Iran or Egypt is exaggragated since during the 2009 "Green revolt" there were only 19,235 Twitter accounts registered or 0,027 per cent of the population and that in Egypt only about 5 percent of its population had access to the Internet at all in 2010 (Morozov 2011). That said, there are still bits of "resistance" from the digitally literate audience, overcoming technical restrictions or prohibitions.

Can one assume that in the digital cultures and with the help of the new media, everybody will become a potentially mnemonic agent to produce, disseminate and consume various reproductions of the past? Or is it more accurate to worry about the "digital amnesia" in the age of a "memory boom" (Huyssen 2003)? The rest of the article will be an attempt to address this question.

\section{Time and Space in Digital Cultures}

The digitization of culture can be evaluated as the last stage of modernity which represents the dissolution of cyclical time tantamount to the time of the "nature" in which the living momentum of traditional societies is adjusted. Change of seasons, annual rituals constitute meaning for life in this type of time. Along with the idea of progress, modernity brings in "the conquest of space, the tearing down of all spatial barriers, and the ultimate 'annihilation of space through time'" (Harvey 1992: 205). The tremendeous changes like the industrial revolution, the rise of capitalism, the technological innovations and colonialism, all result in the readjustment of time and space. The world is rediscovered on the "maps", it is measured by the "chronometers". The idea of scientific knowledge, the faith in progress and the fervent for a more affluent society bring in the "rational" usage of time and space. The rise of the capitalism results in the standardization and homogenization of time in which the management of the clock time is evaluated as a prerequisite for capital and profit. Harvey epitomises the changes in modern societies with the metaphor of "time-space compression" which explains the downsizing of the world along with the technological innovations and communication technologies that result in the "postmodern condition":

Increasingly seen as a mechanical division fixed by the swing of the pendulum, time's arrow was conceived to be linear both forwards and backwards. The conception of past and future as linearly connected by the ticking away of the clock allowed all manner of scientific and historical conceptions to flourish 
(...) And even though it took many years for geological and evolutionary time scales to be accepted, there is a sense in which such time scales were already implicit in the very acceptance of the chronometer as the way of telling time. Even more important, perhaps, was the significance of such a conception of homogeneous and universal time to conceptions of the rate of profit (return on stock of capital over time, said Adam Smith), the rate of interest, the hourly wage, and other magnitudes fundamental to capitalist decision-making. What all this adds up to is the by now well accepted fact that Enlightenment thought operated within the confines of a rather mechanical 'Newtonian' vision of the universe, in which the presumed absolutes of homogeneous time and space formed limiting containers to thought and action. The breakdown in these absolute conceptions under the stress of time-space compression was the central story of the birth of nineteenth and early twentieth-century forms of modernism (Harvey 1992: 252).

The time-space compression enables a "smaller" world where globalisation becomes the rule and the capitalism functions as the major force on change. Global markets, transportation facilities, developments in communication technologies like the invention of the printing, the telegraph or the telephone provide a universally homogenous time which move fastly around the world. Castells's "timeless time" converges "time-space compression" in its criticism of the annihilation of time. While "time-space compression" refers to the changes which modernity brings in and explains them with the concept of the "postmodern condition", "timeless time" stresses the structure and functioning of the network society. According to Castells, "timeless time" implies the desequencing of time with the use of the information and communication technologies:

In the network society, the emphasis on sequencing is reversed. The relationship to time is defined by the use of information and communication technologies in a relentless effort to annihilate time by negating sequencing. This is done, on the one hand, by compressing time (as in split-second global financial transactions or the effort to fight "instant wars"), and, on the other, by blurring the sequence of social practices, including past, present, and future, in a random order, as in the electronic hypertext, or in the blurring of life-cycle patterns (Castells 2004: 37).

Castells's evaluations refer to the shattering of both the biological time -like the experiences of parenting or death- and/or the bureaucratic time which adjusts professional experiences like that of the working hours. The time of the network society seems to be dissolving the time of the industrial societies in which standardisation of time had been the rule for a well-functioning capitalism. Castells's formulation reaches to a deep philosophical debate, asking a fundamental question on the human nature: an ever-changing and evolving "becoming" versus an existence and essence of "being":

In industrial society, organized around the idea of progress and the development of productive forces, becoming structured being, time conformed to space. 
In the network society, the space of flows dissolves time by disordering the sequence of events and making them simultaneous, thus installing society in structural ephemerality: being cancels becoming (Castells 2004: 37).

Both Harvey and Castells stress the transformative power of capitalism in the construction of time. According to Castells, this huge transformation tells the story of capitalism which is forced to renew itself through periodical crisis and to "free itself from all constraints" (Castells 2010: 464) in order to fully function without the limitation of the time or the space. Global markets, interdependent ventures, "mobile" employment, home officing, limit and space free career planning seem to be the concurrent raising values of the "timeless time" and the "space of flows". A central corollary of this process is the interpretation of time as a mobile, liquid and subjective form which negates space and announces the end of the "linear, irreversible, measurable, predictable time" (Castells 2010: 463) of the modernity. Yet there is still a convergence of the time of early modernity and the network society: speed. "Acceleration rather than deceleration [is] the constant leitmotiv of cultural modernity" (Tomlinson 2007: 94). The same assumption is valid for the network society. Speed also constitutes similar side-effects in both types of the structures: "rootlessness" and "mnémotropisme" (Candau 1998: 104) in which the relation with the past and memory become an obsession along with the fear of "loss". The anxiety of speed, rapid changes and vast transformations "hurtle" the modern man. The "invention of traditions" (Hobsbawm\&Ranger 1992), concretization and congealing of the past in the museums, retromania, marketing of mnemonic products, heritage protection schemes, all in all the rise of the nostalgia indicate the morbid relationship of modern societies with the past.

Both the traditional mass media and the new media have a function of mediating the images of the past in this process. Yet the abundance of information carry the potential risk of desensitisation and virtuality. Tele-presence (Virilio 2005: 9) and tele-mediatisation of culture (Tomlinson 2007: 94) symbolise the end of the authentic memory communities. Virtual communities (Virilio 2005) gathering in the "space of flows" share global transformation which create the "digital unconscious". "The mixing of times in the media, within the same channel of communication and at the choice of the viewer, interactor, creates a temporal collage, where not only genres are mixed, but their timing becomes synchronous in a flat horizon, with no beginning, no end, no sequence" (Castells 2010: 492).

The overall result of this transformation is the alienation of the modern man. The obsession of memory comes as an antidote against the capitalist reification, a resistance against the dissolving of the time (Huyssen 1995). New or old, all media function as the primary source of the memory construction and mediation during this process. 


\section{How About the Non-West?: Arrhythmia of the Hybrid Time Layers and the Outflow of the Digital Culture}

The motto of "modernity as a process and modernisation as a project" epitomise the relationship between "the West and the rest" (Hall 1992). Lacking the historical experience of modernity, the non-Western societies go through a "time lag" (Ahıska 2003) which creates and endures strong feelings of belatedness constantly. Colonization, semi-colonization and the effects of the capitalism besiege the non-West gradually, exporting product relations and ideology. "Objective conceptions of time and space are necessarily created through material practices and processes which serve to reproduce social life" (Harvey 1992: 204). The differing character of material production in these societies results in a diversity of interpretations of time and space. One may easily observe the layered characteristic of time and space in the non-Western societies. The elites of these societies who meet the West in "contact zones"7(Pratt 2007) pass to a different phase of culture and relations of production where they face the bits of modernity earlier than the rest of the society. These elites are generally blamed for loosing the ties with their culture and being alienated. As the "time lag" is attempted to be closed by vast, hasty transformations -mostly referring to superstructure- the "time-space compression" and co-existence of different time layers occur. Superstructural changes create "costume modernity" in which hybrid forms of the pre-modern/ modern and post-modern layers of time and space intermingle. The identity crisis lead to search for the "ancient golden ages", status quo antes where again the battle with the "present" harsly continues. These diverse and heterogeneous layers result in cultural schizophrenia (Shayegan 1997) and the hybridity of time and space where social and political polarisation appear as a corollary.

In these societies collective memories flow as veins in social life, without touching each other. Meta-narratives and official memories created by the power elites of an authoritarian or semi-authoritarian political climate, attempt to manage the memory. Yet counter-memories flourish as the pressure on vernacular narratives increase. Official history holds memories captive. The success of modernisation is attributed to the strength of state whose every action may be intepreted as legitimate by the ruling elite. As the political culture turns to become more repressive, counter-memories fade under the ground. The society experiences different time layers in private and in public. Yet there seems to be a strong oral tradition, kind of a generational memory which challenges official history. The arrhythmia of the hybrid time layers turns to political disputes and polarisations in which identities locate themselves in

7 Pratt describes "contact zones" as "the space of colonial encounters, the space in which people geographically and historically seperated come into contact with each other and establishing ongoing relations, usually involving conditions of coercion, radical inequality, and intractable conflict (...)" (Pratt, 1987). 
suppressed or glorified pasts. The past seems to be more vivid than it should be, holding the present captive. Rather than a "society", "communities of memory" dominate quasi public sphere. They endure conflicting, competitive, rival and hostile relations, overshadowing negotiation, common sense or concensus. There exists ongoing disputes on symbols, rituals, even monuments ${ }^{8}$, all that reside in present as "sites of memory" (Nora 1996). Continual fight between "becoming" versus "being" seems to be won by "being". Solid identities construct rigorous images of the past, heroes and stories that challenges time and change. Manipulation and disinformation are used as memory weapons by the organic intellectuals. Settling accounts with the past, apology to the victims overshadow the conscience, converting the confrontation into a political parade. Any matter may turn to "instant memory wars" at any time, revealing the hidden munition.

The non-Western societies like Turkey and Iran which experienced similar modernisation projects (Atabaki and Zücher 2012), have close societal characteristics and relations with the past as epitomised above. Polarisation in the society, authoritarian state traditions, conflicting images of the past and ongoing debates which hold the present captive, all seem to indicate the "cultural schizophrenia" both societies are in. 2009 Iranian protests and 2013 Gezi protests of Turkey reveal the deep fissures in present political debates and their reflections in the collective memory. The usage of the social media during the protests and the "memory wars" indicate the diversified outflow of the digital culture in both societies, becoming an example of different experiences of the new media. It is of importance to discuss and analyze the construction of the past in these debates in comparison with the Western societies.

\section{New Media and the Transformation of Collective Memory}

The conceptualisation of memory in this study is a combination of Halbwachs' and Assmanns' interpretations of the term. Halbwachs' "social frames" (1992) are indispensable because they explain how one gets memories in the social groups, but his division of the historical-autobiographical memory is converted to Assmann's conception of the cultural-communicative memory in this analysis. Communicative memory resembles Halbwach's conceptualisation of autobiographical memory, referring to the memory of the individual that last during his/her lifespan. It constitutes the memory of a generation, limited with the personal memories of its members and it is transmitted through personal interaction (Assmann, 2001). In modern societies, communicative memory is mediated via media, preserved for the making of cultural memory which can be

8 The death of two citizens (one of them is a soldier) during the protests of the removal of the monument of a PKK member in Lice-Turkey, on August, 2014 by military forces, indicate the level of violence and polarisation on issues regarding conflicting memories. http://www.dha. com.tr/mahsum-korkmaz-monument-removed-from-pkk-graveyard-1-killed-2-injured_737189. html [ 31.08. 2014] 
interpreted as society's long-term memory (Donk 2009). The cultural memory holds the material basis for future remembrance in store, it builds a solid ground for the construction of social memories across time (Assmann \& Assmann 1994: 120-122, cited by Donk 2009). So one may say that without the circulation and (re)mediation of the communicative memories, a long term cultural memory can not exist.

Plain logic tells us that the new media would increase the power of cultural memory since the communicative memories could have found more channels to be disseminated. New media create "new memory" which is global, digital and mobile (Garde-Hansen 2011: 44). Yet is this the fact? Dystopian views complain about the new media's reducing, diminishing even destroying the quality of face-to-face communications and making human relations more formal (Kubicek 1988, cited by Dijk 2012), while utopian views challenge this idea through the assertion that along with digital technologies, "new economy" and a new era of prosperity, freedom and online democracy is looming ahead (Dijk 2012: 3). Despite the discussion on the advantages and disadvantages of the new media, what is at stake here is to note that "digital technologies create "mediated memories" which are the activities and objects we produce and appropriate by means of media technologies, for creating and re-creating a sense of past, present and future of ourselves in relation to others" (Dijk 2007: 21). According to Reading,

(...)Digital media technologies and digitization enable the capture and storage, management and reassembly of data records in ways that in relation to earlier mediated memories are less costly, globally connected, and reproducible across different media. Mediated memories of events may be personally and locally produced, before being rapidly mobilized, traveling and settling in multiple, globalized dispersed sites emplaced within various local contexts (Reading 2011: 242)

Garde-Hansen also stresses the power of the internet and the convergence ability of different means in order to foster the making of collective memory:

The internet is distributing memories into personal, corporate and institutional archives. As more media digitally comverge (television, mobile phones, video and photography) there are increased opportunities for museums, broadcasters, public institutions, private companies, media corporations and ordinary citizens to engage in what the philosopher Jacques Derrida once described as archieve fever (1996, cited by Garde-Hansen 2011: 71).

Despite the optimist views on the digital technologies' capacities to contribute to the construction and democratisation of memory, the power of the digital technologies to keep and store information and assist the construction of cultural memory seems in peril due to the technical disadvantages the medium possesses. The fear of the "digital amnesia" -if the network societies pass to 
a phase of digitizing all culture including the preservation of the past- stems from plausible reasons:

1. soft- and hardware evolve in such a fast way that incompatibility between formats seems inescapable,

2. digital media storages like CD, DVD or even hard drives do not outlast for more than 20 years and can be easily deleted,

3. internet and mail communication tend to be elusive as internet sites vanish without being archived (Donk 2009: 7)

The new media's material inadequacies, like the lifespan of the digital technologies may be one source of apprehension. Yet Huyseen shares deeper concerns on the nature of the memory, be it communicative or cultural:

\begin{abstract}
Memory is always transitory, notoriously unreliable, and haunted by forgetting, in brief, human and social. As public memory it is subject to change-political, generational, individual. It cannot be stored forever, nor can it be secured by monuments. Nor, for that matter, can we rely on digital retrieval systems to guarantee coherence and continuity (Huyssen 2003: 28).
\end{abstract}

He also shares his negative assesments on the "mass-marketing memories" that "we consume" as "imagined memories" which are "more easily forgettable than lived memories" (Huyssen 2003: 17). Keightley also notes pessimistly that

\footnotetext{
"We experience the world vicariously through media technologies, but because the experiences delivered to us through these media are decontextualised and disembodied, they are not memorable. They seal us off from our own experience, creating amnesiac subjects" (Keightley 2012: 203-205).
}

Keeping in mind the "nature" of memory, it is important to discuss the possibilities and impossibilities the new media may offer in the construction of cultural memories. The fundamental feature of this form of media is creating an active space where audience can become producer and consumer at the same time as "prosumers" (Lister et. al. 2009). The new media enable "mass self communication" (Dijk 2012), where one may address many. This enables a huge possibility of converging communicative and cultural memories and emancipating memory from official constraints. Think of the death of Neda Agda Sultan once more, and the person who shot and distributed her video to the whole world or the photos of Lobna Allami who suffered a head injury due to a tear gas canister during the Gezi protests. These examples remind the strong power of creating "witnessing" in the new media which is an important form of cultural memory. "Since the performance of witnessing links past presence, the present past, and present presence, it is a prime mechanism for the communicative construction of public memory (Zelizer 2002 cited by Thomas 2009: 98)". It is also a reservoir of potential symbols and sites of memories for 
a prospective collective memory. In a very subtle and recursive process, the act of witnessing contributes to the 'construction' of history and the preservation as well as an accumulation of collective memory (Felman and Laub 1992, cited by Thomas 2009: 98). Yet it must be taken into account that most of the witnessing involve "narrative memories" (Garde-Hansen 2009) and story-telling in which the selection, omitting, embellisihing of the "facts" and emotional redirecting are included. It is also a fact that not all witnessings help the making of collective memory. Imagine a Nazi who published his memoirs at the war as a 'witness' - it might be accepted as an account of experiences, but never as a 'witness' in the moral sense: to witness means to be on the right side (Peters 2009: 30). Given that the counter-witnessing is not evaluated as legitimate, witnessing generally foster in-group memories.

The accumulation and preservation of the "bits" of collective memory constitute the biggest problem in the new media technologies. For instance, does the internet function as an archive? Is it a sufficient source for storing information on the past? Youtube, web pages or blogs may function as stores of memory, but they may not be eligible to function as proper archives. Ernst notes that

The archive is defined as a given, preselected quantity of documents evaluated according to their worth of being handed down. The Internet, on the other hand, is an aggregate of unpredictable texts, sounds, images, data and programs It also has no intrinsic macrotemporal index, as the "year 2000" problem made clear. It operates at a microtemporal level instead (2013: 82-86).

The information load also seems to be a problem for securing data for the future memory. The renewal of memory for presentist reasons in the new media may complicate systematic archive storage. ${ }^{9}$ Despite the digital media's disadvantage to serve as a classical archive, Garde-Hansen claims that it still functions as an "archive" where individual or group memories are stored in. According to her, the digital media function in four ways to store the information on the past: as producing an archive, as an archiving tool, as a self-archiving phenomenon and as a creative archive (2011: 72).

The Digital media produce an archive through heritage and memory preservation mostly as a deliberative activity. Memorial websites like 11 September 2001, or oral witnessing projects like the British Library's Digital Lives Project, or online digital archives like Second World War archives (GardeHansen 2011: 72) may be evaluated as efforts to keep memory digitally preserved. Western societies' will to keep "heritage" preserved professionally and the interest of the public in the past overlap to benefit from the digital

9 It is important to note here that archives never guarantee the preservation of authentic memories. It is a fact that systematic archives or historical documents are preserved according to the needs of the authorities that keep them. Yet in the societies where NGOs function as mnemonic agents, not only official archives, but also "amateur" arhives function as memory keepers. 
technologies efficiently, even as much as to call this process as "heritage industry" (Hewison 1987).

Digital media as an archiving tool does not refer to professional archives as conceptualised above, yet it explains the capacity of information storage via new media through "online music and sound recording collections. Google and Wikipedia might be considered good examples of digital media's archiving power" (Garde-Hansen 2011: 72).

Digital media as a self-archiving phenomenon refers to the new media's ability to keep records of the material it involves without efforts of materially keeping the information. Garde-Hansen notes that "Newspaper archives, blogs, twitter, folksonomies, digg.com, Google Trends and Internet Archive are prime examples of media forms and practices that use themselves to remember themselves" (2011: 72).

Digital media as a creative archive stand for user-generated content where individuals consciously or unconsciously produce the material which may constitute social or individual archive. Facebook, Flickr, smartphone applications, citizen journalism and video game add-ons (Garde-Hansen 2011: 72) may be counted as some of these sources.

Remembering the characteristics of the time and space in the Western and the non-Western societies, a general evaluation may let us determine that the Western societies benefit from the new media's archive potential through all aspects of the medium. Heritage protection as an industry bring in the professional archives and online memory projects where the digital media is used for its rapidly mobilising, easily reachable content that promotes interactive participation. It is also generally used as a "creative archive" on the individual level, assisting to keep autobiographical memories mobile, portable and easily reachable. There is no need to add that the digital media is used as an "archiving and self-archiving tool" itself through all of its means. All these efforts provide the return to the "roots" in a "timeless time" under the pressure of the "timespace compression". Nostalgia enables being the "tourists of history" (Sturken 2007) digitally for sometime and for everybody.

In the case of the non-Western societies, the memory disputes which divide societies vertically and result in the "arrhythmia of the hybrid time layers", effect the utilisation of the digital technologies in which the digital media is mostly used as "a creative archive". Especially the usage of the Facebook and the Twitter evoke "prosthetic memories" which by making possible an unprecedented circulation of images and narratives about the past, make people deeply feel memor[ies] of a past even though which he or she did not live (Landsberg 2004: 2). By all means the past has presentist functions in these cases, serving mostly current political needs. In fact we are now in a 
position where journalists are no longer the first drafters of history at all but Twitter users are (Garde-Hansen 2011:4). Especially during the social events when the mainstream media do not function, the Twitter becomes the primary source of information. Think about the Roboski Massacre in 2011 when the media in Turkey reported the events almost 12 hours belatedly. The only news source had been the Twitter during the case. The Gezi Protests may be counted as another example where citizen journalism functioned as an alternative to the mainstream media and also assisted in the making of a memory reservoir of the events by providing photos, documentaries and mnemonic agents. This process also contributed to "media witnessing" in which

\begin{abstract}
(...) more and more of us create testimony not only because we appear in media ("I was there; this what I saw") but because we can bear witness by media, thanks to the proliferation of cell phone and other miniature cameras that we carry around with us as basic equipment. (...) Media witnessing casts the audience as the ultimate adresse and primary producer, making the collective both the subject and object of everyday witnessing, testifying to its own historical reality as it unfolds. It is the emergence of this collective performance of mundane, perpetual self-affirmation- in, by and through the media- that makes media witnessing not only analytically useful but also culturally significant (Pinchevski and Frosh 2009: 10-12).
\end{abstract}

Hence witnessing converts the audience into active participants in the making of the history and cultural memory along with the help of communicative memories. Besides the texts, visual material is also used in the construction of collective memory in these memory sites. "Home movies", which are counted as an important part of the Western family memory and digitally broadcasted for entertainment, is converted into the "street movies" in countries like Turkey to provide witnessing to demonstrations and/or human rights violations. While "home movies" actually mediate lived experience on an everyday level through sight, sound, movement and touch in order to create multi-modal self-archive (Garde-Hansen 2011: 74), "street movies" function as "counter-memories" and challenge formal state discourses by providing access to an alternative truth, helping to create a community-archive and preserving cultural memory via communicative memories. Photographs and documentaries also assist the visualisation of memory and reinforce witnessing. By the "remediation" (Erll 2012: 111) of these material digitally, events, mnemonic agents and/or places are represented permanently and are transformed into "sites of memories"10.

10 Yet there are still problems of accuracy which may be misleading about the material gathered for collective memory. Communicative memories may be inaccurate, edited and manipulated digitally. Wilson points to this problem: "If online database archives such as YouTube and Wikipedia house artefacts (accounts) of the past that are easily altered and versioned by a simple method of editing, then questions must be raised as to the accuracy of such histories if the artefacts themselves have a versioned remixing of something else (2009: 186). 


\section{Conclusion}

Despite time's being structured and organised differently, the new media and the digital culture seem to be contamined to the most parts of the world. This leads us to think about the forthcoming consequences of these technologies on the construction of culture and societies. An important dimension of this change is our relationship with memory, how we make up our common images of the past. The new media seem to provide technological advantages for the making and distribution of the past images, enabling "mass self communication", also resulting in the genesis of the "prosumers". The internet as an active and passive archive enables to store loads of information while it facilitates cheap access to direct knowledge. Yet scholars in the field seem pessimist about the future of memory. Despite its democratising access to archives (online catalogues, databases) (Donk 2009), most of the scholars agree that the "digital amnesia" and as a result of this the loss of history and collective identity (Assmann 2004, Bertman 2000, Ernst 2002, Osten 2004, Brand 2003 cited by Donk 2009) is on the way.

In my opinion, the new media may bring in new opportunities for the pluralisation of memory channels; it may strenghten counter-memories and enable a voice for the subordinate and the suppressed ${ }^{11}$. Namely they can act as the "alternative media". They may form the precondition for plural cultures of remembrance (mnemonic internet sites), and they relieve human's corporal memory (Donk 2009). A supporting observation for this idea may be the potential usage of the new media technologies in the non-Western countries in the creation of counter-narratives against authoritarian discourses of the past. Keeping in mind "the net delusion" and the potential repressive state power on the digital technologies and people using them, it must be stressed that this would be an ongoing "battle" between opponent sides of the "instant memory wars".

The construction of the past in Western and non-Western societies through the new media stem from the notion of "time" and the historical experiences lead today. While the past is commemorated by heritage industry, retromania, nostalgia and individual memory-making in the Western societies, the arrhythmia of the hybrid time layers in the non-West convert the disputes on the past to memory wars. The new media, especially the social media, is seen as a battlefield to these conflicts. Political polarisation results in the instrumentalisation of the past for presentist political agenda. Specific symbols, mnemonic "heroes", sites of memories endure dialectical zero-sum-games.

11 Remember the families of those who lost their lives during the Gezi protests. Their only channel of communication to the public had been the Twitter or the Facebook. After the Soma mine disaster, miners like Sefa Köken also raised public attention to the events and endured his protests via the Twitter. Twitter also hosts traditional counter-memory movements like Cumartesi Anneleri (the Saturday Mothers). 
One may easily remember the "Rabia versus Gezi" dispute in 2013 in Turkey, creating a set of hostile and polarised atmosphere of memory wars. Yet the new media still stand as an arena of public debate on the past and present where one meets the "Other". Castells seems optimist about this process stating that "the culture of the global network society is a culture of protocols of communication enabling communication between different cultures on the basis, not necessarily of shared values, but of sharing the value of communication" (Castells 2004: 40). So as Keightley stresses, there is always the possibility to evaluate these places as "zones of intermediacy" where participants produce social identities and relationships, in the sense that the multiple temporal constituents of the zones are able to bring into play the time of others. Media and communications technologies also have potential as temporal resources for the construction of deeply felt social identities that are negotiated in the between-times of their temporal frameworks (2012: 217).

All in all, the digital technologies and the new media are used by people -people in flesh and blood-covered by the cultural and historical accumulation of their background. Remembering and forgetting will always be humanly deeds and the medium will always be surrounded by the historical roots of the societies. It is of importance to evaluate and question the contributions of the new media in memory making, certainly deepen the analysis by ampyric and comparative data, yet it is noteworthy to remember that "..we allow collective memories to fabricate, rearrange, elaborate and omit details about the past, 'pushing aside accuracy and authenticity so as to accommodate broader issues of identity formation, power and authority, and political affiliation (Zelizer 1998: $3)^{\prime \prime}$. Rather than the symbols of a disputed past, this may be the first detail we need to commit ourselves to "remember" and to "remind".

\section{References}

AHISKA Meltem (2003), "Occidentalism. The Historical Fantasy of the Modern", The South Atlantic Quarterly 102 (2/3): 351-380.

AITCHISON Jean, LEWIS Diana (Ed.) (2006), New Media Language, London, NY, Routledge.

ASSMANN Jan (2001), Kültürel Bellek: Eski Yüksek Kültürlerde Yazı, Hatırlama ve Politik Kimlik, İstanbul, Ayrıntı.

ATABAKI Touraj, ZUCHER Erik Jan (2012), Türkiye ve İran'da Otoriter Modernleşme: Atatürk ve Rıza Şah Dönemleri, İstanbul, Bilgi Üniversitesi Yayınları.

CASTELLS Manuel (2004), "Informationalism, Networks and the Network Society: A Theoretical Blueprint", Manuel Castells (Ed.) The Network Society, A Cross-cultural Perspective, Edward Elgar Publishing. 
CASTELLS Manuel (2010), The Rise of the Network Society, Wiley Blackwell Publishing.

CANDAU Joel (1998), Mémoire et Identité, Paris, Presses Universtaires de France.

CURRAN James, FENTON Natalie, FREEDMAN Des (2012), Misunderstanding the Internet, New York, Routledge.

DIJCK José Van (2007), Mediated Memories in the Digital Age, Stanford University Press.

DIJK Jan Van (2012), The Network Society, London, Sage Publications.

DONK Andre (2009), "The Digitization of Memory: Blessing or Curse?", Media in Transition Conference "MIT6: Stone and Papyrus, Storage and Transmission", April 24-26, 2009, Massachusetts Institute of Technology, Boston.

DOUEIHI Milad (2011), Digital Cultures, Harvard University Press.

ERLL Astrid (2012), "Remembering Across Time, Space and Cultures: Premediation, Remediation and the 'Indian Mutiny'", Astrid Erll-Ann Rigney (Eds.), Mediation, Remediation and the Dynamics of Cultural Memory, Walter De Gruyter.

ERNST Wolfgang (2013), Digital Memory and the Archive, University of Minnesota Press.

GARDE-HANSEN Joanne, HOSKINS Andrew, READING Anne (Eds.) (2009), Save As: Digital Memories, Palgrave MacMillan.

GARDE-HANSEN Joanne (2011), Media and Memory, Edinburgh University Press.

GITLIN Todd (2011) "Nomadicity", Mark Bauerlin (Ed.), The Digital Divide, Penguin Books.

HALBWACHS Maurice (1992) On Collective Memory, trans. Lewis A, Coser, Chicago, University of Chicago Press.

KEIGHTLEY Emily (2012), "Conclusion: Making Time- The Social Temporalities of Mediated Experience", Emily Keigthley (Ed.), Time, Media and Modernity, London, Palgrave MacMillan.

HALL Stuart (1992), "The West and the Rest", Stuart Hall, Bram Gieben (Ed.), Formations of Modernity, Polity Press.

HARVEY David (1992), The Condition of Postmodernity, An Enquiry Into The Origins of Cultural Change, Blackwell Publishers.

HEWISON Robert (1987), The Heritage Industry: Britain in a Climate of Decline, London, Methuen. 
HOBSBAWM Eric and RANGER Terence (Eds.) (1992), The Invention of Tradition, Cambridge University Press.

HUYSSEN Andreas (1995), Twilight Memories: Marking Time in a Culture of Amnesia, Routledge.

HUYSSEN Andreas (2003), Present Pasts, Urban Palimpsests and the Politics of Memory, Stanford University Press.

KEEN Andrew (2012), Digital Vertigo, New York, St Martin's Press.

LANDSBERG Allison (2004), Prosthetic Memory: The Transformation of American Remembrance in the Age of Mass Culture, Columbia University Press.

LISTER Martin, DOVEY Jon, GIDDINGS Seth, GRANT Iain, KELLY Kieran (Ed.) (2009), New Media: A Critical Introduction, 2nd Edition, London, Routledge.

LOGAN Robert K. (2010), Understanding New Media, Extending Marshall McLuhan, Peter Lang Publishing.

MANOVICH Lev (2001), The Language of New Media, London, The MIT Press.

MOROZOV Evgeny (2011), The Net Delusion, New York, Public Affairs.

NORA Pierre (1996), Realms of Memory: The Construction of the French Past, Vol:1, Columbia University Press.

PINCHEVSKI Amit (2009) and FROSH Paul, "Introduction: Why Media Witnessing? Why Now?", Paul Frosh and Amit Pinchevski (Ed.), Media Witnessing: Testimony in the Age of Mass Communication, New York, Palgrave MacMillan.

PRATT Marie Louise (1987), "Linguistic Utopias", Nigel Fabb et. al (Ed.), The Linguistics of Writing, Manchaster, Manchester University Press.

PRATT Marie Louise (2007), Imperial Eyes:TravelWriting and Transculturation, 2nd Edition, New York, Routledge.

READING Anne (2011), "Memory and Digital Media: Six Dynamics of the Globital Memory Field", Motti Neiger, Oren Meyers, Eyal Zandberg (Ed.), On Media Memory: Collective Memory in a New Media Age, London, Palgrave MacMillan.

READING Anne (2012), "Globital Time: Time in the Digital Globalised Age", Emily Keightley (Ed.) Time, Media and Modernity, London, Palgrave MacMillan.

SCHÖNBERGER-MAYER Viktor (2009), Delete: The Virtue of Forgetting in the Digital Age, Oxford, Princeton University Press.

SHAYEGAN Daryush (1997), Cultural Schizophrenia: Islamic Societies Confronting the West, Syracuse University Press. 
STURKEN Marita (2007), Tourists of History: Memory, Kitsch and Consumerism from Oklahoma City to Ground Zero, Durham, NC, Duke University Press.

THOMAS Günter (2009), "Witness As a Cultural Form of Communication: Historical Roots, Structural Dynamics And Current Appearances", Paul Frosh and Amit Pinchevski (Eds), Media Witnessing: Testimony in the Age of Mass Communication, New York, Palgrave MacMillan.

THUMIM Nancy (2012), Self-Representation and Digital Culture, Palgrave MacMillan.

TOMLINSON John (2007), The Culture of Speed, The Coming of Immediacy, Sage Publications.

VIRILIO Paul (2005), The Information Bomb, Trans. by: Chris Turner, London, Verso.

WILSON Shaun (2009), "Remixing Memory in Digital Media", Joanne GardeHansen et. al (Eds.), Save As: Digital Memories, Palgrave MacMillan.

ZELIZER Barbie (1998), Remembering to Forget: Holocaust Memory through the Camera's Eye, Chicago, Chicago University Press. 